\title{
Management Responsibility of National Student Loans in Colleges and Universities based on the perspective of stakeholder theory
}

\author{
Duan Kaige $^{1}$, Li Yong ${ }^{2}$ \\ ${ }^{1}$ Female, Master, School of foreign languages, Jinan University, Guangzhou, 510632, China; \\ ${ }^{2}$ Corresponding author, Male, Doctor, Director of General Office, Students' Affairs Division, Jinan \\ University, Guangzhou, 510632, China. \\ E-mail: 6617798@qq.com
}

Keywords: student loans; responsibility; stakeholder

\begin{abstract}
The national student loans is a policy-related loans which is dominated by the government, universities and students. Based on the stakeholder theory, the paper is to analyze interests needs and conflicts of parties involved in national student loans centered at universities, explored the ways to realize the maximization of the interests of all stakeholders.
\end{abstract}

\section{Introduction}

In September 2015, the National Student Financial Assistance Administration of the Ministry of Education and the Bank of China Ltd. Signed the 2015-2018 National Student Loans Strategic Cooperation Agreement in Beijing, representing a new round of national student loans policy in full swing. Cooperation agreement re-identified responsibilities and obligations of parties involved in the national student loans. Especially, the determination of the responsibility and power of the universities caused widespread concern in this field. Although the national student loans keep making continuous improvement in the implementation process, there are still problems like bank credit crunch, students' low repayment rate and other issues, leading to national student loans in a virtuous circle. Therefore, many scholars have made a lot of research on the causes and improvement measures from the perspectives of law, finance, government management and universities management. And some scholars think that the fundamental reason is that the government failure, so the government should bear the risk of default of loans, reduce the interest rate, recovery, the establishment of joint credit system and a series of responsibilities [1]. According to some scholars, universities negligence in being a middleman between banks and students and in taking repayment for students who get a loans are to blame for the loans in vicious circle[2]. Based on the stakeholder theory, this paper is to make an in-depth analysis of the interests and needs of the universities and other three stakeholders, and is to redefine the management responsibility of the universities in the implementation of the national student loans policy.

\section{Analysis of universities-centered stakeholders in national student loans}

Stakeholder theory is a theoretical proposition that western economists put forward when studying corporate governance. It is widely used to study corporate social responsibility. Stakeholder theory advocates:

(1)All stakeholders (including shareholders, employees, customers, distributors, suppliers, lenders, consumers, regulators, governments, etc.) affected by the business are involved in business decision-making.

(2)The manager has a fiduciary responsibility to serve the interests of all stakeholders;

(3)The goal of the enterprise should be to promote the interests of all stakeholders and not just shareholders [3].

Stakeholder theory argues that firms should be at a higher perspective to consider their relationship with all stakeholders and the whole society, and should assume some social 
responsibility. The goal of the enterprise is no longer to maximize the interests of shareholders, but maximize the collective interests or the interests of their own enterprises, so as to maximize the overall interests of stakeholders.

Compared with the enterprise stakeholders, the national student loans are government-led, and have the joint participation of the bank, the universities and the students. Just because of this, the government, banks, universities, and student formed a more typical and special interest community. This kind of special interest relationship makes the national student loans have no strictly subject and deputy body, and each of the related parties can't exercise independent control of this policy loans. Only by the joint control of stakeholders can assure the smooth implementation of the policy.

Because of the special policy-implementation status, colleges and universities should maintain national goals, national interests and national policy with the government and timely feedback on the implementation of advice, need to coordinate and urge banks to apply for loans, approval, payment and repayment and maintenance of students interests and other related business, but also shouldering the promotion and guidance to students in the national student loans policy, integrity and sense of thanksgiving education and high-quality personnel training, but these three aspects in the policy implementation process is not directly contacted, so the author believes that colleges and universities is the special stakeholder which have the most communication, emotion connect with the government, the bank and the student and have the most obvious role of the bridge, thus playing a more central and key role in ensuring the smooth operation of the current loans subsidy system than other tripartite stakeholders.

The new policy of the national student loans ensure the main responsibility for the universities. The universities should not only be responsible for the main propaganda work of the national student loans and the qualification examination of the loans students, but also should be responsible for the establishment of the student loans management system, After the management at the same time.

College need to strengthen the integrity of education and moral education to prevent the risk of loans. As a result, colleges and universities not only become the organizer of the national student loans work, but also the manager of student loans. However, in the four subjects of the national student loans, the colleges and universities is the most special interest group, it is not as independent as the other three subjects, its status and role is not clear. It can't directly benefit from the student loans and isn't directly responsible for the risk of student default, but also can't adjust the national policy independently. Therefore, in the complex national student loans system project, the power and responsibility, the role and the inclination of interests make universities bear certain responsibility for the problems existing in the management of student loans.

\section{Analysis of the interest demand of universities - linked stakeholders}

As a government action, the national student loans is a complicated and mixed tool which integrates policy, welfare, education and finance. Direct participant include bank, school, loans students and government, and become a relatively independent stakeholder system. The two direct aims of the national student loans system are to solve the difficult problems of poor students and to alleviate the arrears of colleges and universities. Around the above two purposes and according to the theory of stakeholders, in the student loans stakeholder system, every main stakeholders have to bear some responsibilities, but none of the main stakeholder will bear full responsibility. As a special type of stakeholder in this system, the universities' accurate positioning of management responsibility is beneficial to the maximization of the overall interests of the stakeholders.

(1)The interest demand and conflict between the universities and the government.

For the government, the financing of poor students, development of education and sustainable development, not only are goals of students and higher education, but also are the purpose of the country. Through the support to poor students and the protection of higher education and social sustainable development, the country implements the Strategy of Developing the Country through Science and Education, thus ensuring the sustainable development of society and maintaining social harmony and stability. Therefore, for the government, the social value is the primary value of the 
national student loans, and the realization of the public interest is the basic, primary goal.

"Higher Education Law of the People's Republic of China," Chapter XIII Article 32 clearly pointed out: "Institutions of higher learning should take personnel training as the center, carry out teaching, scientific research and social services, and guarantee the quality of education and teaching to meet the standards prescribed by the national [4]. "Therefore, colleges and universities should take teaching, scientific research and serving the society as their main tasks, and assisting banks in handling national aid loans is only one item attached to the management functions of institutions of higher learning. Besides, stakeholder theory argues that all stakeholders have the power to participate in business decisions. But according to China's current national student loans system, the universities, don't have the power to participate in decision-making, they are just the executors.

There are differences in tasks and interest demand between the government and the universities, which determine that the universities and the government cannot form a joint force in the face of the student loans policy. The enthusiasm and autonomy of the universities can't be fully exploited.

(2)The demand and conflict between the bank and colleges and universities

China's "Commercial Bank Law" provides that commercial banks' goal is the pursuit of profit maximization, the implementation of independent management, self-financing market players, any units and individuals have no right to force banks to issue loans [5]. Therefore, commercial banks should be in accordance with the commercialization, market-oriented mode of operation, emphasis on security, liquidity and profitability. For commercial banks, the proceeds from the national student loans are low, the cost is high and the risks are large. Loans student customers are in contradiction with the financial target groups. Especially the huge risks are difficult to be effectively controlled and the compensation mechanism is not perfect, resulting in low profit loss. Thus, reducing the supply of loans has become a necessary rational choice. Although the administrative order can make the national-owned commercial banks continue to issue loans, it cannot meet the needs of the national student loans and can't solve the problem of sustainable development of national student loans. At the same time, when the commercial banks apply for student loans, they will face with colleges and universities rather than directly the loans students, causing the original simple two-dimensional relationship to a complex three-dimensional relationship between banks and students, based on this, business banks should seize the universities as a loans object of lending objects, take it as an access to the campus to develop financial customers, open up the window of financial affairs in colleges and universities, and treat the student loans which needs to be taken seriously as a "tasteless" business.

As a national student loans business supervisors, performers, under the existing national policy conditions, in order to ensure the normal operation of school funding, colleges and universities always compromise with commercial banks, colleges and universities not only safeguard the fundamental interests of students but also be subject to the rules of the commercial banks, ending in a dilemma which passively led by banks.

The differences in tasks and interest demand between the bank and the universities, determines that the universities and the commercial banks cannot form a joint force in the face of the student loans policy, and the enthusiasm and autonomy of the universities cannot be fully exploited.

(3)Interest demand and conflict among college students

According to Saharapolis's "Education investment return rate", the personal income of higher education is far greater than the social benefits, so students are the largest beneficiary group; for schools, it can guarantee the tuition fees, minimize the occurrence of tuition arrears, and alleviate the financial pressure caused by insufficient investment in education.

Compared to government, banks and universities, the role of students during school is the most passive one, students can only passively take policies, documents, instructions and information from the above three stakeholders. The main task of the student is supposed to be learning, but because of the student loans, these students have to bear more mental stress than other students, and a series of forms to fill, data submission, contract signing, loans tracking, academic registration, repayment education and integrity training seriously affect the students of the normal learning time, the most fundamental need of students is to acquire knowledge as a specialized talent, a series 
of tedious affairs will inevitably impact students' study and life, which is contrary to their basic interests.

Colleges and universities are transmission microphones of information to loans students. Under the condition that loans student information system failed to achieve the stakeholders to share the case, the universities often obtained the information of loans students through commercial banks. the untimely update, incomplete and inaccurate of information query easily lead to college students information tracking delay, especially for the loans repayment information tracking delay. Compared with the government and commercial banks, colleges and universities have a better understanding of the daily life of loans students, and are easier to find out the loans students' school information and personal quality. Colleges and universities' interests of the demand for students is only to ensure to provide quotas to students in need, and make the loans students in a timely manner repayment.

\section{Discussion and Thoughts}

The national student loans is a good policy for the benefit of the country and can't aim at maximizing the individual interests of either party. The decision of the student loans must seek a balance between the stakeholders. Although the colleges and universities are in a relatively passive position compared to the government and commercial banks, they can play a pivotal role in the process of successful implementation of the national student loans policy because of the bond position.

(1) Colleges and universities should take the initiative to assume the national student loans policy advocacy task

Colleges and universities should take the initiative to do a good job of national student loans propaganda work, increase publicity efforts, make full use of a variety of publicity platform to promote the national student loans policy ,in order to make loans conditions, application procedures and repayment methods and other specific content be known by the majority of students and families,. The purpose is to enable students to know that the national student loans is a social-benefiting policy which reflects the attention and care from the country to the students with financially difficulties, and also to enable students and parents to understand the national student loans are commercial bank loans, There is a credit relationship that is permanently associated with the student's individual and the family.

(2)Colleges and universities should forwardly take the responsibility of giving the government feedback about advantages and disadvantages on the implementation of student loans policy.

Colleges and universities are in the first line of national student loans work, and have the best understanding of the implementation of the policy problems, so that it's necessary to make colleges and universities to participate in student loans policy development. At the same time, colleges and universities need to urge the government to actively change the function and to provide advice and suggestions for the government in the student loanss information network system construction.

(3)Colleges and universities should forwardly take the responsibility of creating social credit environment by utilizing the first and second classes

At present, the overall social environment integrity awareness is weak. Colleges and universities only lock the object of honest education in loans student groups. When the loans students come into the community and find that the social environment and reality is different with their education, their fragile sense of integrity is bound defeated. College students is a major consumer group in the future society, and also the main creator of the future social credit environment, colleges and universities should make full use of the first class for all college students and open the financial knowledge of the elective courses, to cultivate students to establish a market economy and society of lending and life view, strengthen the sense of integrity. At the same time colleges and universities can also through the second class, campus network and school newspaper and professionals lectures asked the relevant personnel to carry out lectures to teach the relevant financial knowledge, for all college students to establish the correct credit and integrity awareness, so as to lay the foundation for the future social integrity environment. 
(4)Colleges and universities should take the initiative to help banks to check the information of loans students.

National student loans is basically simple loans relationship between commercial banks and loans students. Under the condition that China's personal credit system has not been able to meet the same use of personal employment, medical care and pension, the bank's decision to applicants for loans can only depend on the materials provided by the school and the students. Therefore, colleges and universities should establish the method of identifying students with financial difficulties in the family. Scientific formulation, confirmation basis, standardized, reasonable and impartial implementation of the accreditation process. At the same time, colleges and universities should strengthen the daily management of loans, establish database of loans' information, to achieve the school management department, employment guidance center and student information network, and tell the bank about the loans students status changes and disciplinary records, etc., so that the bank can change the loans agreement in time, which reduce the risk of bank loans to recover from the source.

(5)Colleges and universities should take the initiative to assume the loans students' cultural concern

Mostly from poor families, they are the direct beneficiaries of national student loans and are grateful to governments, schools and banks. Student loans reduce their economic pressure and psychological burdens during their studies, giving them a degree of equal access to higher education, changing the fate of many students from economically disadvantaged families, continuing their college dreams and continuing the whole family's hope. However, when faced with graduation work is not implemented but the loans began to repay, these students will bear great mental stress, so they need colleges and universities to intervene to give human care, employment guidelines and coordination of bank flexible repayment in time, to avoid loans graduates change the feelings from gratitude to hate the society.

\section{Acknowledgement}

The work was supported by research project of student aid in Guangdong colleges and Universities with the project number 2009ZXZC002 and the project name Research on university student management responsibility of national student loans.

\section{Reference}

[1]Liu Jinsong, Zhou Daren. Government responsibility and accountability path in student loans [J]. academic forum, 2006, (2):196-198.

[2] Tang Xiaojiong. Analysis of the reasons and Countermeasures of the slow development of national student loans from the perspective of school[J]. Economist, 2009, (1):73-74.

[3] JOHNR BOATRIGHT. Contractors as stakeholders: reconciling stakeholder theory with the Nexus-of-Con-tracts Film[J]. Journal of Banking andFinance2002, (26): 1837-1852

[4] Wang Ying, Zhao Lixia. Study on the scope of responsibility of colleges and universities in the national student loans [J]. Higher Education Research, 2004, (6):32-34.

[5] Tian Xueping, Liu Wenjuan. Analysis of the plight of national subsidized student loans from the perspective of stakeholders [J]. Journal of Inner Mongolia universities of Finance and Economics Edition), 2008, (1): 12-15. 